\title{
Aquatic insects as the main food resource of fish the community in a Neotropical reservoir
}

\author{
Ana Paula Vidotto-Magnoni and Edmir Daniel Carvalho
}

We evaluated the feeding of fish species of the Nova Avanhandava Reservoir, low Tietê River, São Paulo State, Brazil. Fishes were collected in two stretches of the reservoir: Santa Bárbara (14 samples) and Bonito (two samples) between September 2002 and March 2004, using gill and seining nets. The results of stomach contents analysis were expressed with the frequency of occurrence and gravimetric method, combined in the Alimentary Index (AI). The 20 species studied consumed 52 food items, grouped in 10 food categories: aquatic insects, terrestrial insects, crustaceans, fish, macroinvertebrates, microcrustaceans, algae, vegetal matter, detritus/sediment and scales. The aquatic insects (mainly Chironomidae, Odonata and Ephemeroptera) were the most common food resources, consumed by 18 species. The diet composition of the community (species grouped) indicated that the dominant food category in the diet of fishes was aquatic insects ( $\mathrm{AI}=77.6 \%$ ), followed by crustaceans (AI $=7.1 \%$ ). Four trophic guilds were identified according a cluster analysis (Pearson distance): insectivorous (10 species), omnivorous (4 species), detritivorous (3 species) and piscivorous/carcinophagous (3 species). Despite the highest number of species, the insectivorous guild was responsible for more than $80 \%$ in captures in number and biomass (CPUEn and CPUEb). The low values of niche breadth presented by all species, along with the low values of diet overlap between species pairs indicate a high degree of food resources partitioning among species. The aquatic insects, despite being the main food resource of insectivorous fishes, also complemented the diet of other species, which demonstrate the importance of this food resource for the fish community, sustaining a high diversity, abundance and biomass of fishes.

Neste estudo foi avaliada a dieta das espécies de peixes do reservatório de Nova Avanhandava, baixo rio Tietê, Estado de São Paulo, Brasil. Os peixes foram coletados em dois trechos do reservatório: trecho Santa Bárbara (14 coletas) e trecho Bonito (duas coletas) entre setembro de 2002 e março de 2004, utilizando-se de redes de espera e arrasto. Os resultados das análises de conteúdo estomacal foram expressos em frequência de ocorrência e método gravimétrico, combinados no Índice Alimentar (IAi). As 20 espécies analisadas consumiram um total de 52 itens, agrupados em 10 categorias alimentares: insetos aquáticos, insetos terrestres, crustáceos, peixes, macroinvertebrados, microcrustáceos, algas, material vegetal, detrito/sedimento e escamas. Os insetos aquáticos (principalmente Chironomidae, Odonata e Ephemeroptera) foram o recurso alimentar mais comum na dieta, consumido por 18 espécies. A análise da dieta da comunidade (espécies agrupadas) revelou que a categoria alimentar dominante foi insetos aquáticos ( $\mathrm{IAi}=77.6 \%)$, seguida pelos crustáceos $(\mathrm{IAi}=7.1 \%)$. Quatro guildas tróficas foram identificadas pela análise de agrupamento (distância de Pearson): insetívoros (10 espécies), onívoros (4 espécies), detritívoros (3 espécies) e piscívoros/carcinófagos (3 espécies). Além do maior número de espécies, os insetívoros também foram responsáveis por mais de $80 \%$ das capturas em número de exemplares e biomassa (CPUEn e CPUEb). Os baixos valores de amplitude de nicho trófico apresentados por todas as espécies, juntamente com os baixos valores de sobreposição alimentar demonstram uma ampla partilha de recursos alimentares entre as espécies. Apesar de ser o principal recurso alimentar dos peixes insetívoros, os insetos aquáticos também foram um recurso complementar na dieta de outras espécies, o que demonstra a importância destes para a comunidade de peixes, sustentando uma alta diversidade, abundância e biomassa de peixes neste reservatório.

Key words: Fish feeding, Trophic ecology, Resource availability, Zoobenthos.

Laboratório de Biologia e Ecologia de Peixes, Departamento de Morfologia, Instituto de Biociências de Botucatu, Universidade Estadual Paulista - UNESP. Distrito de Rubião Jr., s/n, 18.600-000 Botucatu, SP, Brazil. anavidotto@gmail.com (APVM), carvalho@ibb.unesp.br (EDC) 


\section{Introduction}

Studies of trophic structure and resource partitioning of fish assemblages are important for the understanding of ecological relationships among fish species and with other aquatic organisms, which can support management of natural populations (Agostinho et al., 1995; Woodward \& Hildrew, 2002). In fish communities, the abundance of trophic guilds is greatly dependent on environment conditions. Some can present a high abundance of piscivorous fishes, especially in the first years of closure of reservoirs, since there is a high abundance of prey (Mérona et al., 2001, 2003). Omnivorous fish may be abundant in environments with seasonal variations, such as in the Pantanal floodplain (Resende, 2000). Detritivorous fish are abundant in some reservoirs (Carvalho et al., 1998; Alvim \& Peret, 2004) and floodplains (Peretti \& Andrian, 2004), where the detritus and sediment are important in the maintenance of fish fauna, leading to increases in the energetic efficiency of the community, and promoting the cycling of the matter and nutrients.

In reservoirs, the main food resources consumed by the fish fauna are originated in the aquatic system, such as aquatic insects, other invertebrates, zooplankton, detritus and fish (Agostinho et al., 2007), sustaining a great diversity and abundance of fishes (Araújo-Lima et al., 1995). Among aquatic insects, several groups are abundant in Neotropical reservoirs, especially dipterans of the family Chironomidae, ephemeropterans and odonats (Higuti et al., 2005; Hahn \& Fugi, 2007). These organisms have an important role in the metabolism of aquatic systems (Pereira \& De Luca, 2003), and as food resource for fishes in streams (Pouilly et al., 2006; Pinto \& Uieda, 2007) and higher order rivers (Horeau et al., 1998). They are also significant food resource for fishes in reservoirs (Arcifa \& Meschiatti, 1993; Callisto et al., 2002; Luz-Agostinho et al., 2006).

The aim of this study was to characterize the feeding ecology of the fish community of a Neotropical reservoir (Nova Avanhandava Reservoir, low Tietê River, São Paulo State, Brazil), and to access the importance of aquatic insects for the trophic structure of this fish community.

\section{Material and Methods}

\section{Study site and samplings}

The Nova Avanhandava Reservoir, located at $358 \mathrm{~m}$ of altitude, is the fifth reservoir of the Tietê River cascade, built in 1982 for hydroelectricity generation. The reservoir has a surface area of $210 \mathrm{~km}^{2}$, total water volume of $2.720 \times 10^{6} \mathrm{~m}^{3}$, mean discharge rate of $688 \mathrm{~m}^{3} . \mathrm{s}^{-1}$, maximum depth of $30 \mathrm{~m}$ and water permanence time of 46 days (Torloni et al., 1993; Rodgher et al., 2002). According to the energy company AES Tietê, variation in the level of the water was almost insignificant in the period studied (357.9 to $358.3 \mathrm{~m}$ ).

The fish were collected in two stretches of the reservoir, the Santa Bárbara $\left(21^{\circ} 05^{\prime} 25^{\prime}\right.$ 'S 50 $07^{\prime} 18^{\prime}$ 'W) and the Bonito (2117'50"S 5008'17'W) (Fig. 1). The fish samplings were carried out monthly between September 2002 and August 2003. In the Santa Bárbara stretch it also occurred in October and December 2003, and March 2004 (14 samples); and in July 2003 and March 2004 in the Bonito stretch.

Fish were caught in six sites of each stretch, using gillnets with mesh sizes from 3 to $14 \mathrm{~cm}$ (opposite knot lengths). Gill nets were placed in the littoral and deeper zones in the afternoon and removed in the following morning (14 hours of exposure). We also used a seining net ( $10 \times 1.5 \mathrm{~m}, 5 \mathrm{~mm}$ mesh) occasionally in some months to capture young fish of some species that occurred in low frequency in gill nets. Nets were handled by two individuals and dragged three times into aquatic vegetation and margin of the reservoir. Fish collected were identified to species, weighed ( $0.01 \mathrm{~g}$ approximation) and measured (total and standard length), preserved in $10 \%$ formalin and conserved in $70^{\circ} \mathrm{GL}$ alcohol. Voucher specimens were deposited in the Museu de Zoologia - Universidade Estadual de Londrina (MZUEL 4729 to MZUEL 4760), Londrina, Paraná.

A sub-sampling of all sizes of each species was performed (about 10 individuals of each species per sampling), and stomach with contents were removed and preserved in 10\% formalin. In the laboratory, these stomachs were transferred to $70^{\circ} \mathrm{GL}$ alcohol.

\section{Diet analysis}

Stomach contents were analyzed under a stereoscopic microscope, identified to the most detailed taxonomic level

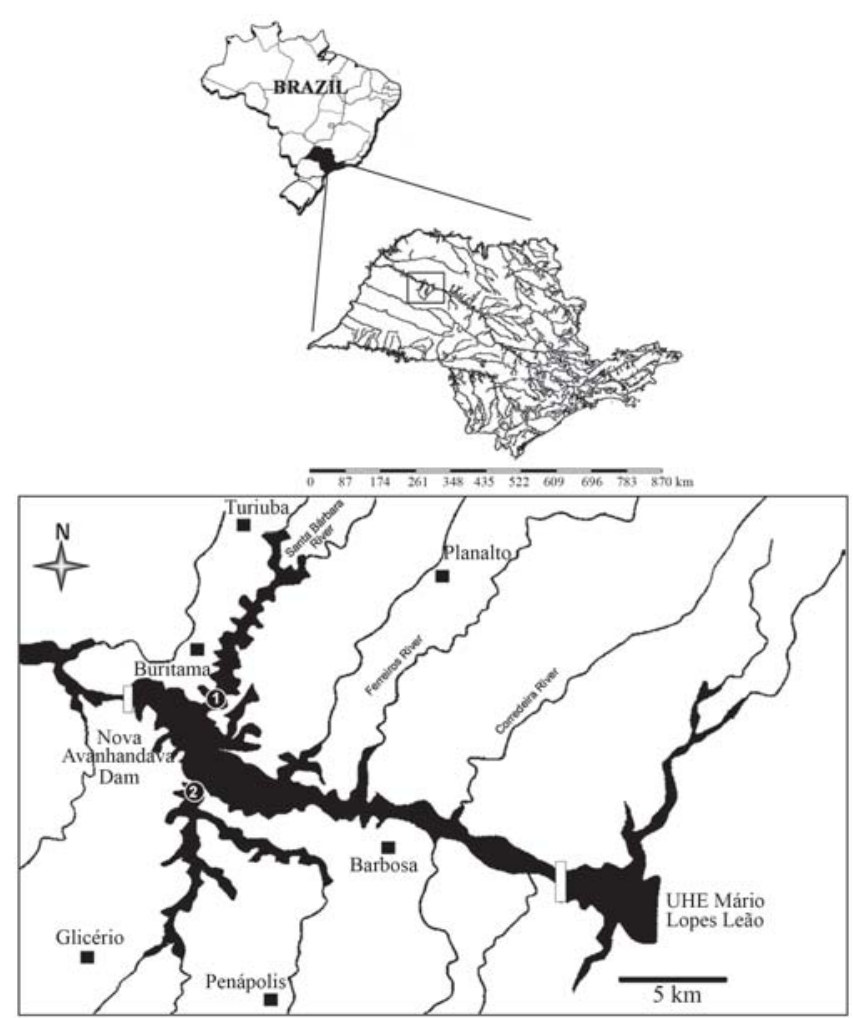

Fig. 1. Position of the Nova Avanhandava Reservoir in the Tietê River, and the location of the sampling stretches: Santa Bárbara stretch (1) and Bonito Stretch (2) (modified from CESP, 1998). Squares $=$ municipalities of São Paulo State. 
possible and weighed (wet weight) on a scale with $0.0001 \mathrm{~g}$ approximation; when this procedure was not possible (for small items), we established a percentage of total content weight (Hynes, 1950). The results were expressed as the frequency of occurrence and gravimetric method (Hyslop, 1980), combined in the Alimentary Index (Kawakami \& Vazzoler, 1980).

Fish consumed 52 food items, grouped in 10 categories: aquatic insects = remains, Coleoptera, Lepidoptera, Diptera (Chironomidae, Ceratopogonidae and Chaoboridae), Ephemeroptera (Caenidae and Polymitarcyidae), Thichoptera (Polycentropodidae and Leptoceridae), Odonata (Libelullidae, Gomphidae and Coenagrionidae) and Hemiptera (Notonectidae); terrestrial insects = remains, Diptera, Hymenoptera, Coleoptera, Hemiptera, Trichoptera, Isoptera, Lepidoptera, Orthoptera, Thysanoptera, Homoptera and Blattodea; crustaceans = crabs and Macrobrachium sp.; fish = entire, scales, muscles and bones; macroinvertebrates = Mollusca, Araneae, Acarina, Hirudinea and invertebrate eggs; microcrustaceans = Cladocera, Copepoda and Ostracoda; algae = diverse groups of unicellular and filamentous algae; vegetal matter = stalks, leaves, roots, seeds in different digestion stages; detritus/sediment = all kinds of bottom material, organic film, mud and sand, and scales $=$ without fish remains.

Fish were grouped into trophic guilds according to a cluster analysis performed with the data of relative weight of food categories, using the Pearson distance and UPGMA amalgamation method. The analysis was computed with the software Statistica 5.1 (StatSoft, Inc., 1996).

The contribution of trophic guilds to the community was calculated as the percentage of CPUE in number of individuals (CPUEn) and biomass (CPUEb), expressed as number or kg of fishes by $1000 \mathrm{~m}^{2}$ of gill nets, during 14 hours of exposure (Agostinho \& Gomes, 1997). Fish caught with seining nets were not included in the CPUE, due to the differences in the catch effort.

The relative level of diet specialization of the species (niche breadth) was calculated by the Levin's index (Hurlbert, 1978):

$$
\mathrm{B}_{i}=\left[\left(\Sigma \mathrm{P}_{i j}{ }^{2}\right)^{-1}-1\right] \cdot(\mathrm{n}-1)^{-1}
$$

where $\mathrm{B}_{i}$ is the niche breath standardized index, $\mathrm{P}_{i j}$ is the proportion of the food item $j$ in the diet of $i$ species and $n$ is the number of food items. The $B$ value ranges from 0 (species consumed mainly one food resource) to 1 (species consumed all food resources in similar proportions). The values of niche breadth were arbitrarily considered high $(>0.6)$, intermediate (0.4 - 0.6) or low (<0.4) (Novakowski et al., 2008).

The diet overlap between species was calculated with the relative weight of food items, using the Pianka Index (1973):

$$
\theta_{j k}=\frac{\sum \mathrm{P}_{i j} \cdot \mathrm{P}_{i k}}{\sqrt{\sum\left(\mathrm{P}_{i j}{ }^{2}\right) \cdot \sum\left(\mathrm{P}_{i k}{ }^{2}\right)}}
$$

where: $\theta_{j k}=$ Pianka's measure of diet overlap index between $j$ and $k$ species; $\mathrm{P}_{i j}=$ proportion resource $i$ of the total resources used by species $j ; \mathrm{P}_{i k}=$ proportion resource $i$ of the total resources used by species $k$; $\mathrm{n}=$ total number of resource states. This index varies from 0 (no overlap) to 1 (total overlap). The overlap values were arbitrarily considered high $(>0.6)$, intermediate (0.4 - 0.6) or low (<0.4) (Novakowski et al., 2008).

A null model was used to evaluate the significance of the food overlap between species (Gotelli \& Entsminger, 2007). The matrix was randomized 10,000 times, using the following options: niche breadth retained and zeroes reshuffled (RA3, Winemiller \& Pianka, 1990). The mean overlap observed is compared to the mean overlap calculated in the null distribution ( $\mathrm{p}<0.05$ ). The feeding overlap and null model analysis were computed using EcoSim 7.0 (Gotelli \& Entsminger, 2007).

\section{Results}

A total of 544 stomachs from 20 species had the contents analyzed (Table 1). The most widely consumed food resources were aquatic insects (mainly Chironomidae, Libelullidae and Polymitarcyidae; 18 fish species; 90\% of the total species); vegetal matter (17 species), detritus/sediment and macroinvertebrates (15 species) and microcrustaceans, terrestrial insects and fish (12 species).

The diet composition of the community (all species grouped) indicated that the dominant food category in the diet of species was aquatic insects, with $\mathrm{AI}=77.6 \%$, followed by crustaceans $(\mathrm{AI}=7.1 \%)$ and vegetal matter (5.2\%) (Fig. 2). The other food resources represented about $10 \%$ of the diet of the community.

Four trophic guilds were determined by the cluster analysis:

Insectivorous: Astyanax altiparanae, Geophagus proximus, Gymnotus carapo, Moenkhausia intermedia, Plagioscion squamosissimus, Rhamdia quelen, Satanoperca pappaterra, Serrasalmus maculatus, Sternopygus macrurus and Triportheus nematurus that feed preferentially on aquatic and terrestrial insects, using different items to complement their diet, such as fish, shrimp, microcrustaceans, algae and detritus.

Omnivorous: Apareiodon affinis, Schizodon nasutus, Tilapia rendalli and Metynnis maculatus, that feed mainly on vegetal fragments, aquatic insects and detritus in similar proportions.

Detritivorous: Steindachnerina insculpta, Oreochromis niloticus and Leporinus friderici, which feed exclusively on detritus or complement their diet with aquatic insects, fish and vegetal matter.

Piscivorous/carcinophagous: one strict piscivorous (Acestrorhynchus lacustris) and two species that feed on fish and shrimps (Hoplias malabaricus and Cichla kelberi).

The trophic structure of the community, represented by the abundance and biomass of trophic guilds indicate that the most abundant guild was insectivorous, with CPUEn = 82.7\% and CPUEb $=81.5 \%$ (Fig. 4). In this guild, $P$. squamosissimus, $S$. pappaterra and $S$. maculatus were the most 
Table 1. Number of stomachs analyzed, standard length (Ls) width (cm), CPUE in number and biomass and diet composition (relative Alimentary Index) and Niche Breadth (B) of the fish species from the Nova Avanhandava Reservoir. Food categories: $\mathrm{AI}=$ Aquatic insect; $\mathrm{TI}=$ Terrestrial insects; $\mathrm{CR}=$ Crustaceans; FI = Fish; $\mathrm{MA}=$ Macroinvertebrates; $\mathrm{MI}$ = Microcrustaceans; $\mathrm{AL}=$ Algae; $\mathrm{VM}=$ Vegetal matter; DS = Detritus/sediment; SC = Scales. In bold = values $\geq 50 \%$; $=$ values $<0.1$.

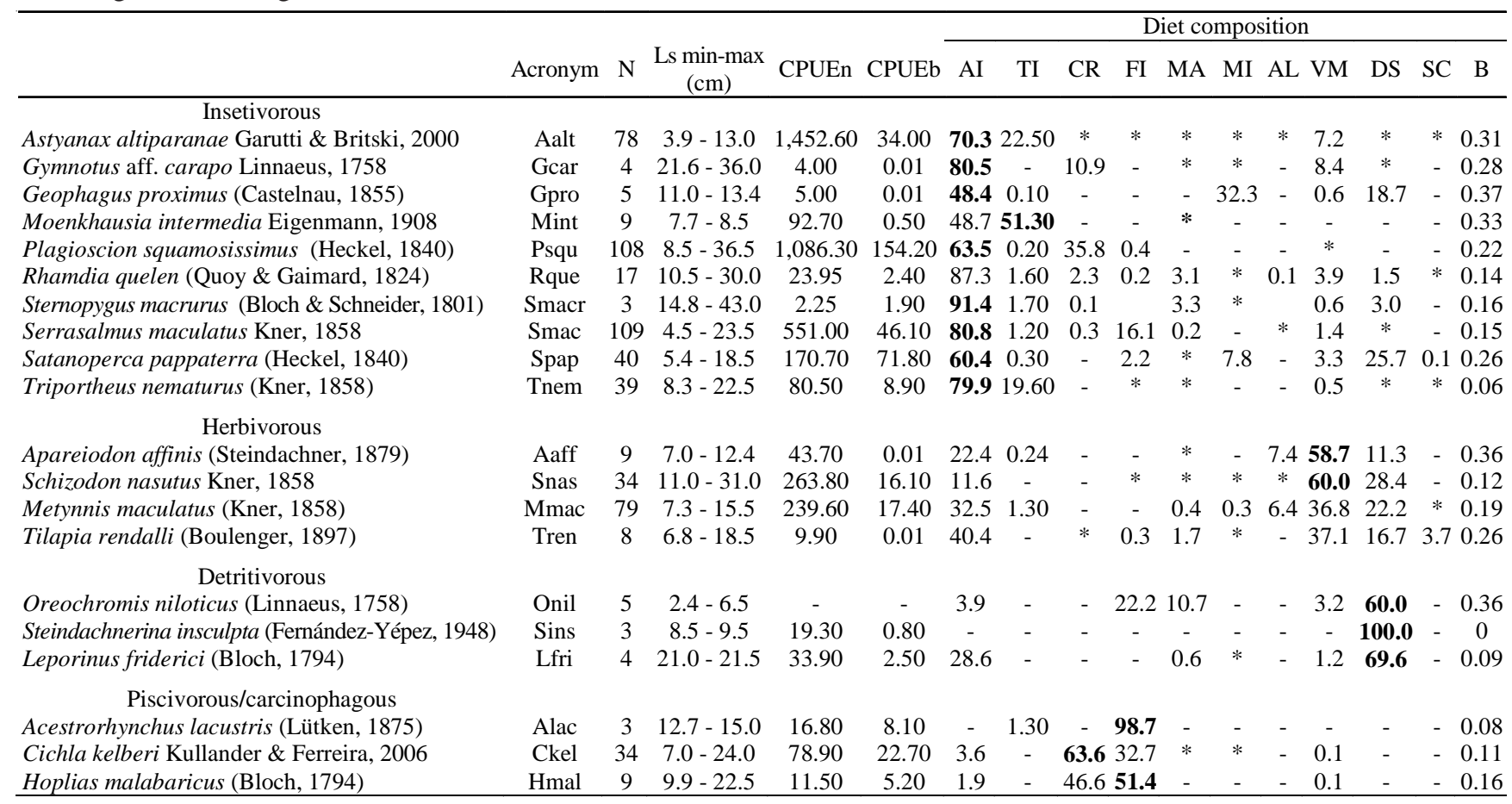

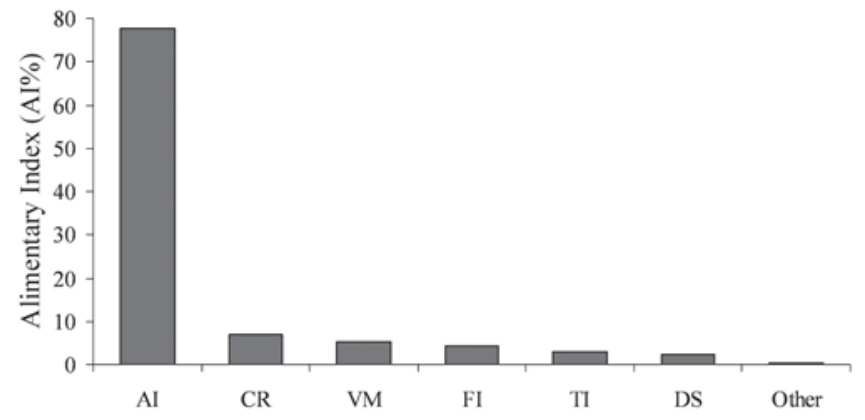

Fig. 2. Alimentary Index (\%) of food categories consumed by the fish community of the Nova Avanhandava Reservoir. AI = Aquatic insect; $\mathrm{TI}$ = Terrestrial insects; $\mathrm{CR}$ = Crustaceans; FI = Fish; MA = Macroinvertebrates; $\mathrm{MI}=$ Microcrustaceans; $\mathrm{AL}=$ Algae; $\mathrm{VM}$ = Vegetal matter; $\mathrm{DS}$ = Detritus/sediment; $\mathrm{SC}=$ Scales. The acronyms of species are in Table 1 .

important in CPUEb (39.3, 18.3 and $11.8 \%$, respectively) and $A$. altiparanae, $P$. squamosissimus and $S$. maculatus in CPUEn (34.7, 25.9 and $13.2 \%$, respectively). The omnivorous guild was the second most important guild in CPUEn (13.3\%), followed by piscivorous-carcinophagous in CPUEb (9.2\%) (Fig. 4).

Within the insectivorous guild, the majority of species were observed to be aquatic insect feeders, except $M$. intermedia, which consumed most terrestrial insects (particularly Hymenoptera). Despite occupying the same trophic guild, species differ in the items consumed. Gymnotus carapo, $R$. quelen, $P$. squamosissimus and $S$. macrurus consumed mostly Odonata nymphs (Libellulidae and Gomphidae and non-identified fragments), while S. maculatus and $T$. nematurus consumed mainly Ephemeroptera Polymitarcyidae nymphs and sub-imagos. Diptera Chironomidae larvae and pupae were important items in the diet of A. altiparanae, $M$. intermedia, $R$. quelen and $S$. pappaterra. In addition, many species from other trophic guilds, such as A. affinis and T. rendalli complemented their diet with this food item.

Aquatic insects that presented a high occurrence in the diet of species were Chironomidae (17 species; preferential item in 7 species), followed by Libellulidae (11 species, preferential item in 5) and Polymitarcyidae (6 species, preferential item in 4). Odonata Gomphidae was eaten by eleven species, and three species demonstrated preference for this item. Niche breadth presented low values for all species (mean $=0.20$ ), varying from 0 (S. insculpta) to 0.37 (G. proximus), indicating that species has a restrict diet, consuming preferentially a small number of food items (Table 1).

The feeding overlap were greater than expected by chance ( $p<0.00001)$, indicating that the values did not occur at random. The values of diet overlap were low (mean $=0.17$ ) for $85 \%$ of species pairs (Table 2). Species that presented intermediate or high diet overlap were mainly from the same trophic guild. Among insectivorous fishes, the intermediatehigh values occurred in $22 \%$ of species pairs (10 interactions), while for all species pairs of herbivorous, detritivorous and piscivorous/carcinophagous intermediate or high values of 


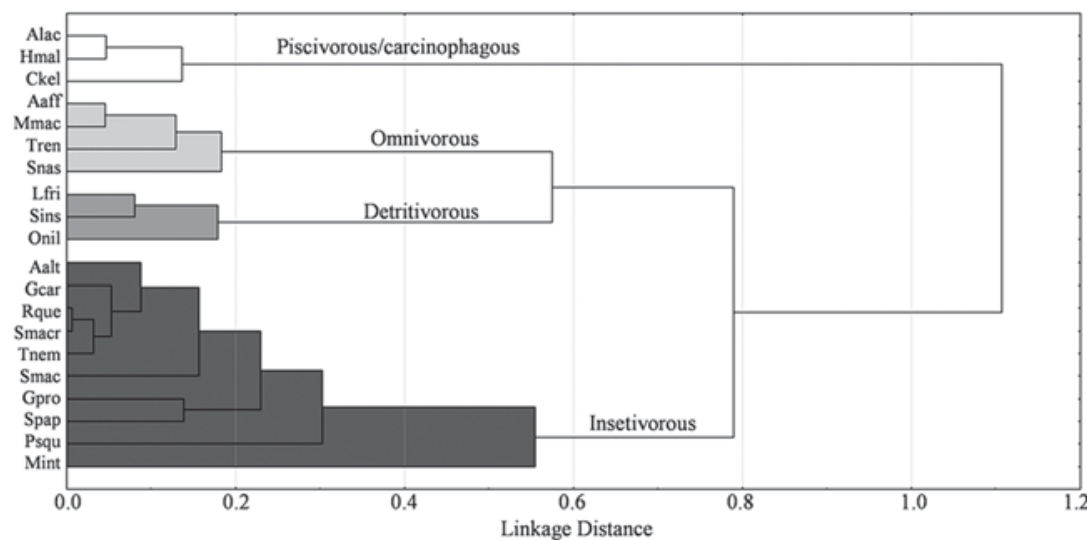

Fig. 3. Cluster analysis of diet similarity among species, showing the trophic guilds of the fish community from the Nova Avanhandava Reservoir.

overlap were observed. Other eight values of intermediate or high overlap happened among fishes from different guilds, but that share some resources, such as detritus, vegetal matter and shrimp (Table 2).

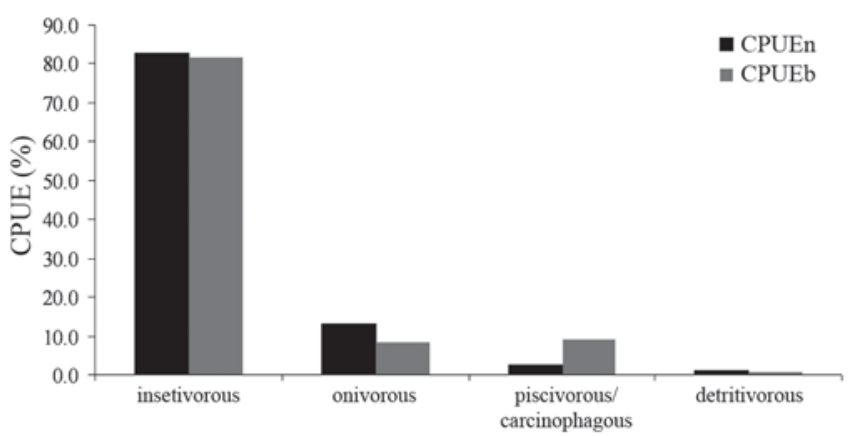

Fig. 4. Relative catch per unit effort (CPUE) in number (CPUEn) and biomass (CPUEb) of trophic guilds of the fish community of the Nova Avanhandava Reservoir.

\section{Discussion}

In the Nova Avanhandava Reservoir, ten species used aquatic insects (mainly Chironomidae, Odonata and Ephemeroptera) and terrestrial insects as their main food resource, and all the other species, in some extent, complemented their diet with these food resources, indicating that aquatic insects are the main food resource in this reservoir. Despite aquatic insects are an important food resource for fishes in floodplains (Hahn et al., 1997b) and in recently impounded rivers (Luz-Agostinho et al., 2006), the insectivorous fishes are not the dominant trophic guild in the majority of Brazilian reservoirs (Agostinho et al., 2007).

In this reservoir, the highest captures in number and biomass of fish occur in the littoral zones (Vidotto \& Carvalho, 2007), which can explain the high consumption of aquatic insects by many species. The littoral zones presents high spatial heterogeneity due to the presence of macrophytes

Table 2. Feeding overlap (Pianka's Index) between fish species from the fish community of Nova Avanhandava Reservoir. In bold $=$ intermediate $(\geq 0.40)$ and high $(\geq 0.60)$ overlap.

\begin{tabular}{lcccccccccccccccccc}
\hline & Aaff & Aalt & Ckel & Gpro & Gcar & Hmal & Mmac & Mint & Onil & Psqu & Rque & Spap & Snas & Smac & Sins & Smacr & Tren & Tnem \\
\hline Alac & 0 & 0.01 & $\mathbf{0 . 4 6}$ & 0 & 0 & $\mathbf{0 . 7 4}$ & 0 & 0 & 0.35 & 0.01 & 0.01 & 0.05 & 0 & 0.31 & 0 & 0.01 & 0.01 & 0.01 \\
Aaff & - & 0.25 & 0.01 & 0.12 & 0.26 & 0.01 & $\mathbf{0 . 6 3}$ & 0.12 & 0.07 & 0.01 & 0.30 & 0.31 & $\mathbf{0 . 8 9}$ & 0.06 & 0.05 & 0.01 & $\mathbf{0 . 9 7}$ & 0.07 \\
Aalt & - & - & 0.02 & 0.19 & 0.33 & 0.01 & 0.11 & $\mathbf{0 . 6 9}$ & 0.01 & 0.16 & $\mathbf{0 . 6 7}$ & $\mathbf{0 . 4 6}$ & 0.11 & $\mathbf{0 . 5 9}$ & 0 & 0.26 & 0.29 & 0.15 \\
Ckel & - & - & - & 0.01 & 0.28 & $\mathbf{0 . 9 4}$ & 0.01 & 0.01 & 0.16 & $\mathbf{0 . 7 3}$ & 0.10 & 0.03 & 0.01 & 0.15 & 0 & 0.01 & 0.01 & 0.01 \\
Gpro & - & - & - & - & 0.07 & 0.01 & 0.29 & 0.09 & 0.38 & 0.02 & 0.14 & 0.29 & 0.22 & 0.03 & 0.29 & 0.02 & 0.12 & 0.05 \\
Gcar & - & - & - & - & - & 0.21 & 0.16 & 0.04 & 0.01 & $\mathbf{0 . 7 9}$ & $\mathbf{0 . 7 9}$ & 0.16 & 0.23 & 0.25 & 0 & $\mathbf{0 . 7 6}$ & 0.26 & 0.04 \\
Hmal & - & - & - & - & - & - & 0.01 & 0.01 & 0.26 & $\mathbf{0 . 5 5}$ & 0.07 & 0.04 & 0.01 & 0.24 & 0 & 0.01 & 0.01 & 0.01 \\
Mmac & - & - & - & - & - & - & - & 0.05 & $\mathbf{0 . 5 9}$ & 0.01 & 0.16 & 0.17 & $\mathbf{0 . 8 0}$ & 0.03 & $\mathbf{0 . 4 2}$ & 0.01 & $\mathbf{0 . 5 8}$ & $\mathbf{0 . 5 1}$ \\
Mint & - & - & - & - & - & - & - & - & 0 & 0.01 & 0.24 & 0.21 & 0.05 & 0.33 & 0 & 0.02 & 0.13 & 0.10 \\
Onil & - & - & - & - & - & - & - & - & - & 0.01 & 0.02 & 0.02 & $\mathbf{0 . 4 4}$ & 0.11 & $\mathbf{0 . 6 6}$ & 0.01 & 0.05 & 0.01 \\
Psqu & - & - & - & - & - & - & - & - & - & - & $\mathbf{0 . 5 1}$ & 0.05 & 0.01 & 0.16 & 0.00 & $\mathbf{0 . 4 9}$ & 0.01 & 0.02 \\
Rque & - & - & - & - & - & - & - & - & - & - & - & 0.38 & 0.20 & 0.35 & 0.02 & $\mathbf{0 . 8 4}$ & 0.32 & 0.09 \\
Spap & - & - & - & - & - & - & - & - & - & - & - & - & 0.14 & 0.07 & $\mathbf{0 . 4 9}$ & 0.10 & $\mathbf{0 . 4 3}$ & 0.21 \\
Snas & - & - & - & - & - & - & - & - & - & - & - & - & - & 0.04 & 0.29 & 0.01 & $\mathbf{0 . 8 6}$ & 0.03 \\
Smac & - & - & - & - & - & - & - & - & - & - & - & - & - & - & 0 & 0.10 & 0.08 & 0.02 \\
Sins & - & - & - & - & - & - & - & - & - & - & - & - & - & - & & 0.05 & 0.20 & 0.01 \\
Smacr & - & - & - & - & - & - & - & - & - & - & - & - & - & - & & - & 0.02 & 0.01 \\
Tren & - & - & - & - & - & - & - & - & - & - & - & - & - & - & & - & - & 0.07 \\
\hline
\end{tabular}


and woody debris that allow the colonization of a diversified associated fauna, such as crustaceans and aquatic insects (Oliveira et al., 2005). They are abundant food resources for species of diverse trophic guilds (Hahn et al., 1997b), sustaining great fish diversity in these regions of reservoirs (Gido et al., 2002).

In the littoral regions, aquatic insects have a great ability to colonize different types of substratum, such as sediment (Covich et al., 1999), leaves, bulks, stones and macrophytes (Fulan \& Henry, 2006). This wide distribution in the water body allows the capture by different Neotropical fish that present diverse feeding tactics: the bottom-feeders, such as S. pappaterra and G. proximus, since they also consumed detritus and sediment; the surface feeders, such as $T$. nematurus and S. maculatus, which capture large amounts of sub-imagos of Ephemeroptera, probably at the moment of their migration to emerge (Hahn et al., 1997b); and species that feed near macrophyte stands, where the Odonata nymphs and Chironomidae are abundant (Fulan \& Henry, 2007), such as A. altiparanae, P. squamosissimus, G. carapo, S. macrurus and $R$. quelen.

The insectivorous species A. altiparanae, $P$. squamosissimus and $S$. maculatus are dominant in terms of CPUEn and CPUEb in this reservoir (Vidotto \& Carvalho, 2009), and widespread in several Brazilian reservoirs (Agostinho et al., 1995). Astyanax altiparanae is widely recognized for its great trophic plasticity and ecological valence (Agostinho et al., 1999), and ability in colonizing recently-impounded reservoirs (Dias et al., 2005) and other environments (Orsi et al., 2004). In this reservoir, this species presented a diet based on Chironomidae larvae and Polymitarcyidae nymphs, complemented with terrestrial Hymenoptera, characterizing a strict insectivorous diet. Casatti et al. (2003) observed the preference for terrestrial insects in the Rosana Reservoir (Paranapanema River). However, under certain conditions, A. altiparanae seem to prefer vegetal matter and seeds (Cassemiro et al., 2002); under other conditions the species is omnivorous, consuming both vegetal and animal matter (Bennemann et al., 2005), demonstrating the high trophic plasticity of this species in different environments.

Plagioscion squamosissimus, an introduced species, was first registered in the commercial catch around 1980 in this reservoir (Torloni et al., 1993). This species, widely described as piscivorous (Almeida et al., 1997; Hahn et al., 1997a), presented Odonata nymphs and shrimp as their main food resources in Nova Avanhandava Reservoir. In stretches under the influence of the Capivara Reservoir (Paranapanema River), Bennemann et al. (2006) observed that, since the introduction of corvina in 1992 to 2002, this species switched their diet from fish (mainly A. altiparanae) to shrimps, due to the reduction in the abundance of prey species, and to the fact that this species is not a selective predator, eating all prey that is available.

Serrasalmus maculatus, another species generally known as piscivorous (Hahn et al., 1998; Agostinho et al., 2003), based its diet mainly on Polymitarcyidae sub-imagos and Gomphidae nymphs in the Nova Avanhandava Reservoir. The aquatic insects comprised a great part of the diet of small specimens (Ls $<5 \mathrm{~cm}$ ) of S. spilopleura (= S. maculatus) analyzed by Casatti et al. (2003). Costa et al. (2005) observed a trophic ontogeny in the diet of $S$. spilopleura $(=S$. maculatus), where individuals with Ls from 6 to $12 \mathrm{~cm}$ consumed aquatic insects, but individuals larger than $12 \mathrm{~cm}$ preferred fish, becoming exclusively piscivorous at $22 \mathrm{~cm}$. In the present study, this feeding habit was observed in individuals with Ls from 4.5 to $23.5 \mathrm{~cm}$, indicating that even adult fish prefer aquatic insects in the Nova Avanhandava Reservoir.

Despite the high number of food items explored, all species presented low values of niche breadth, indicating the use of a limited number of resources. The high dominance by few resources suggest their abundance in the environment (Novakowski et al., 2008), and is not related to morphological limitations to the consumption of specific resources.

Low diet overlap values were observed in almost all species pairs, indicating that species present differences in the diet composition. These results, combined with the low niche breadth of all species suggest a high degree of food partitioning among species, and has been observed in other fish communities of the Neotropical region (Uieda et al., 1997; Esteves et al., 2008; Novakowski et al., 2008; Mérona \& Rankin-de-Mérona, 2004). However, when overlap was analyzed independently within each trophic guild, some different patterns were observed. Among insectivorous fishes, the trophic guild with the greatest number of species, few species pair presented overlap values higher than 0.4 , indicating a spatial segregation in the use of the food resources, that may be due to differences in the strategies of foraging, as discussed above. Within the detritivorous and herbivorous only intermediate or high values of overlap were observed, but these species share abundant food resources, such as detritus and vegetal matter, and may use these resources opportunistically (Mathews, 1998). For fishes from the piscivorous/carcinophagous guild, the difficulty in the identification of many preys may have interfered in the results, due to the high stage of digestion of the fishes. Nevertheless, even when species present high niche overlap other factors can allow coexistence, such as spatial heterogeneity and habitat complexity, combined with environmental, temporal, population and behavioral aspects (Schoener, 1974; May, 1986).

In conclusion, we observed that aquatic insects play an important role in the maintenance of the fish community of the Nova Avanhandava Reservoir, sustaining a high diversity of species and abundance of fish. In addition, species present different feeding styles, independent of the trophic position, leading to a plentiful partitioning of the food resources.

\section{Acknowledgements}

Authors thank the Brazilian Nature Conservancy (TNC) for financial support and São Paulo State Research Foundation (FAPESP) for the scholarship granted to the first 
author (proc. n ${ }^{\circ}$ 02/11113-6); we thank Oscar A. Shibatta (UEL) for identification of fish specimens and Ricardo A. S. Teixeira, Renato Devidé and staff of Laboratório de Biologia e Ecologia de Peixes (Depto. Morfologia, IB, UNESP - Botucatu) for helping in field works.

\section{Literature Cited}

Agostinho, A. A. \& L. C. Gomes. 1997. Manejo e monitoramento de recursos pesqueiros: perspectivas para o reservatório de Segredo. Pp. 319-364. In: Agostinho, A. A. \& L. C. Gomes (Orgs.). Reservatório de Segredo: Bases Ecológicas Para o Manejo. Maringá, Eduem, 387p.

Agostinho, A. A., L. C. Gomes \& F. M. Pelicice. 2007. Ecologia e Manejo de Recursos Pesqueiros em Reservatórios do Brasil. Maringá, Eduem, 501p.

Agostinho, C. S., N. S. Hahn \& E. E. Marques. 2003. Patterns of food resource use by two congeneric species of piranhas (Serrasalmus) on the Upper Paraná River floodplain. Brazilian Journal of Biology, 63(2): 177-182.

Agostinho, A. A., L. E. Miranda, L. M. Bini, L. C. Gomes, S. M. Thomaz \& H. I. Suzuki. 1999. Patterns of colonization in Neotropical reservoirs, and prognoses on aging. Pp. 227-265. In: Tundisi, J. G. \& M. Straskraba (Eds.). Theoretical reservoir ecology and its applications. São Carlos, Editora IIE, 255p.

Agostinho, A. A., A. E. A. de M. Vazzoler \& S. M. Thomaz. 1995. The high river Paraná basin: limnological and ichthyologycal aspects. Pp. 419-446. In: Tundisi, J. G., C. E. M. Bicudo \& T. Matsumura-Tundisi (Eds.). Limnology in Brazil. Rio de Janeiro, Academia Brasileira de Ciências e Sociedade Brasileira de Limnologia, 384p.

Almeida, V. L. L., N. S. Hahn \& A. E. A de M. Vazzoler. 1997. Feeding patterns in five predatory fishes of the high Paraná River floodplain (PR, Brazil). Ecology of Freshwater Fish, 6(3): 123-133.

Alvim, M. C. C. \& A. C. Peret. 2004. Food resources sustaining the fish fauna in a section of the upper São Francisco River in Três Marias, MG, Brazil. Brazilian Journal of Biology, 64(2): 195202.

Araújo-Lima, C. A. R. M., A. A. Agostinho \& N. N. Fabré. 1995. Trophic aspects of fish communities in Brazilian rivers and reservoirs. Pp. 105-136. In: Tundisi, J. G., C. E. M. Bicudo \& T. Matsumura-Tundisi (Eds.). Limnology in Brazil. Rio de Janeiro, Brazilian Academy of Sciences/Brazilian Limnological Society, 384p.

Arcifa, M. S. \& A. J. Meschiatti. 1993. Distribution and feeding ecology of fishes in a Brazilian reservoir: Lake Monte Alegre. Interciencia, 18(6): 302-313.

Bennemann, S. T., L. G. Capra, W. Galves \& O. A. Shibatta. 2006. Dinâmica trófica de Plagioscion squamosissimus (Perciformes, Sciaenidae) em trechos de influência da represa Capivara (rios Paranapanema e Tibagi). Iheringia, Série Zoologia, 96(1): 115119.

Bennemann, S. T., A. M. Gealh, M. L. Orsi \& L. M. Souza. 2005. Ocorrência e ecologia trófica de quatro espécies de Astyanax (Characidae) em diferentes rios da bacia do Rio Tibagi, Paraná, Brasil. Iheringia, Série Zoologia, 95(3): 247-254.

Callisto, M., V. Vono, F. A. R. Barbosa \& S. M. Santeiro. 2002. Chironomidae as a food resource for Leporinus amblyrhynchus (Teleostei: Characiformes) and Pimelodus maculatus (Teleostei: Siluriformes) in a Brazilian reservoir. Lundiana, 3(1): 67-73.
Carvalho, E. D., V. F. B. Silva, C. Y. Fujihara, R. Henry \& F. Foresti. 1998. Diversity of fish species in River Paranapanema Jurumirim Reservoir transition region (São Paulo, Brazil). Italian Journal of Zoology, 65(1): 325-330.

Casatti, L., H. F. Mendes \& K. M. Ferreira. 2003. Aquatic macrophytes as feeding site for small fishes in the Rosana Reservoir, Paranapanema River, Southeastern Brazil. Brazilian Journal of Biology, 63(2): 213-222.

Cassemiro, F. A. S., N. S. Hahn \& R. Fugi. 2002. Avaliação da dieta de Astyanax altiparanae Garutti \& Britski, 2000 (Osteichthyes, Tetragonopterinae) antes e após a formação do reservatório de Salto Caxias, Estado do Paraná, Brasil. Acta Scientiarum, Biological Sciences, 24(2): 419-425.

Costa, A. C., L. F. Salvador Jr., F. F. T. Domingos \& M. L. Fonseca. 2005. Alimentação da pirambeba Serrasalmus spilopleura Kner, 1858 (Characidae, Serrasalminae) em um reservatório do Sudeste brasileiro. Acta Scientiarum, Biological Sciences, 27(4): 365-369.

Covich, A. P., M. A. Palmer \& T. A. Crowl. 1999. The role of benthic invertebrate species in freshwater ecosystems. BioScience, 49(2): 119-127.

Dias, R. M., D. Bailly, R. R. Antônio, H. I. Suzuki \& A. A. Agostinho. 2005. Colonization of the Corumbá Reservoir (Corumbá River, Paraná River basin, Goiás State, Brazil) by the "lambari” Astyanax altiparanae (Tetragonopeterinae, Characidae). Brazilian Archives of Biology and Technology, 48(3): 467-475.

Esteves, K. E., A. V. P. Lobo \& M. D. R. Faria. 2008. Trophic structure of a fish community along environmental gradients of a subtropical river (Paraitinga River, Upper Tietê River Basin, Brazil). Hydrobiologia, 598(1): 373-387.

Fulan, J. A. \& R. Henry. 2006. The Odonata (Insecta) assemblage on Eichhornia azurea (Sw.) Kunth (Pontederiaceae) stands in Camargo Lake, a lateral lake on the Paranapanema River (State of São Paulo, Brazil), after an extreme inundation episode. Acta Limnologica Brasiliensia, 18(4): 423-431.

Fulan, J. A. \& R. Henry. 2007. Distribuição temporal de imaturos de Odonata (Insecta) associados a Eichhornia azurea (Kunth) na Lagoa do Camargo, Rio Paranapanema, São Paulo. Revista Brasileira de Entomologia, 51(2): 224-227.

Gerking, S. D. 1994. Feeding ecology of fishes. San Diego, Academic Press, 416p.

Gido, K. B., C. W. Hargrave, W. J. Matthew, G. D. Schnell, D. W. Pogue \& G. W. Sewell. 2002. Structure of littoral-zone fish communities in relation to habitat, physical, and chemical gradients in a southern reservoir. Environmental Biology of Fishes, 63: 253-263.

Gotelli, N. J. \& G. L. Entsminger, 2007. EcoSim: Null models software for ecology. Version 7.0. Jericho, Vermont, Acquired Intelligence Inc. \& Kesey-Bear. Available from: http:// garyentsminger.com/ecosim.htm

Hahn, N. S., A. A. Agostinho \& R. Goitein. 1997a. Feeding ecology of curvina Plagioscion squamosissimus (Heckel, 1840) (Osteichthyes, Perciformes) in the Itaipu Reservoir and Porto Rico floodplain. Acta Limnologica Brasiliensia, 9(1): 11-22.

Hahn, N. S., A. A. Agostinho, L. C. Gomes \& L. M. Bini. 1998. Estrutura trófica da ictiofauna do reservatório de Itaipu (ParanáBrasil) nos primeiros anos de sua formação. Interciencia, 23(5): 299-305.

Hahn, N. S., I. F. Andrian, R. Fugi \& V. L. L. Almeida. 1997b. Ecologia trófica. Pp. 209-228. In: Vazzoler, A. E. A. M., A. A. Agostinho \& N. S. Hahn (Eds.). A planície de inundação do Alto rio Paraná: aspectos físicos, biológicos e socioeconômicos. Maringá, Eduem/Nupélia, 460p. 
Hahn, N. S. \& R. Fugi. 2007. Alimentação de peixes em reservatórios brasileiros: alterações e conseqüências nos estágios iniciais do represamento. Oecologia Brasiliensis, 11(4): 469-480.

Higuti, J., I. P. Zviejkovski, M. A.Takahashi \& V. G. Dias. 2005. Chironomidae indicadora do estado trófico em reservatórios. Pp. 137-146. In: Rodrigues, L., S. M. Thomas, A. A. Agostinho \& L. C. Gomes (Orgs.). Biocenoses em reservatórios. Padrões espaciais e temporais. São Carlos, Rima, 333p.

Horeau, V., P. Cerdan, A. Champeau \& S. Richard. 1998. Importance of aquatic invertebrates in the diet of rapids-dwelling fish in the Sinnamary River, French Guiana. Journal of Tropical Ecology, 14: 851-864.

Hurlbert, S. H. 1978. The measurement of niche overlap and some relatives. Ecology, 59: 67-77.

Hynes, H. B. N. 1950. The food of fresh-water Sticklebacks (Gasterosteus aculeatus and Pygosteus pungitius), with a review of methods used in studies of the food of fishes. Journal of Animal Ecology, 19(1): 36-58.

Hyslop, E. J. 1980. Stomach contents analysis - a review of methods and their application. Journal of Fish Biology, 17(4): 411-429.

Kawakami, E. \& G. Vazzoler. 1980. Método gráfico e estimativa de índice alimentar aplicado no estudo de alimentação de peixes. Boletim do Instituto Oceanográfico, 29(2): 205-207.

Loureiro-Crippa, V. E. \& N. S. Hahn. 2006. Use of food resources by the fish fauna of a small reservoir (rio Jordão, Brazil) before and shortly after its filling. Neotropical Ichthyology, 4(3): 357-362.

Luz-Agostinho, K. D. G., L. M. Bini, R. Fugi, A. A. Agostinho \& H. F. Julio, Jr. 2006. Food spectrum and trophic structure of the ichthyofauna of Corumbá Reservoir, Paraná River basin, Brazil. Neotropical Ichthyology, 4(1): 61-68.

Matthews, W. J. 1998. Patterns in Freshwater Fish Ecology. Massachusetts, Chapman \& Hall, 756p.

May, R. 1986. The search for patterns in the balance of nature: advances and retreats. Ecology, 67: 115-1126.

Mérona, B. \& J. Rankin-de-Mérona. 2004. Food resource partitioning in a fish community of the central Amazon floodplain. Neotropical Ichthyology, 2(2): 75-84.

Mérona, B., G. M. Santos \& R. G. Almeida. 2001. Short term effects of Tucuruí dam (Amazonia, Brazil) on the trophic organization of fish communities. Environmental Biology of Fishes, 60(4): 375-392.

Mérona, B., R. Vigouroux \& V. Horeau. 2003. Changes in food resources and their utilization by fish assemblages in a large tropical reservoir in South America (Petit-Saut Dam, French Guiana). Acta Oecologica, 24(3): 147-456.

Novakowski, G. C., N. S. Hahn \& R. Fugi. 2008. Diet seasonality and food overlap of the fish assemblage in a pantanal pond. Neotropical Ichthyology, 6(4): 567-576.

Oliveira, E. F., C. V. Minte-Vera \& E. Goulart. 2005. Structure of fish assemblages along spatial gradients in a deep subtropical reservoir (Itaipu Reservoir, Brazil-Paraguay border). Environmental Biology of Fishes, 72(3): 283-304.

Orsi, M. L., E. D. Carvalho \& F. Foresti. 2004. Biologia populacional de Astyanax altiparanae Garutti \& Britski (Teleostei, Characidae) do médio Rio Paranapanema, Paraná, Brasil. Revista Brasileira de Zoologia, 21(2): 207-218.

Pereira, D. \& S. J. De Luca. 2003. Benthic macroinvertebrates and the quality of the hydric resources in Maratá Creek basin (Rio Grande do Sul, Brazil). Acta Limnologica Brasiliensia, 15(2): 57-68.

Peretti, D. \& I. F. Andrian. 2004. Trophic structure of fish assemblages in five permanent lagoons of the high Paraná River floodplain, Brazil. Environmental Biology of Fishes, 71: 95-103.
Pianka, E. R. 1973. The structure of lizard communities. Annual Review of Ecology and Systematics, 4: 53-74.

Pinto, T. L. F. \& V. S. Uieda. 2007. Aquatic insects selected as food for fishes of a tropical stream: Are there spatial and seasonal differences in their selectivity? Acta Limnologica Brasiliensia, 19(1): 67-78.

Pouilly, M., S. Barrera \& C. Rosales. 2006. Changes of taxonomic and trophic structure of fish assemblages along an environmental gradient in the Upper Beni watershed (Bolivia). Journal of Fish Biology, 68(1): 137-156.

Reis, R. E., S. O Kullander \& C. J. Ferraris, Jr. (Orgs.). 2003. Check list of the freshwater fishes of South and Central America. Porto Alegre, Edipucrs, 729p.

Resende, E. K. 2000. Trophic structure of fish assemblages in the lower Miranda river, Pantanal, Mato Grosso do Sul State, Brazil. Revista Brasileira de Biologia, 60(3): 389-403.

Rodgher, S., E. L. G. Espíndola, R. Fracácio, M. H. Rodrigues, R. H. G. Pereira \& O. Rocha. 2002. Estudos ecotoxicológicos nos reservatórios em cascata do médio e baixo rio Tietê: uma avaliação dos impactos ambientais. Pp. 131-144. In: PPG - CEA. Recursos Hidroenergéticos: Usos, Impactos e Planejamento Integrado. São Carlos, RIMA, 360p.

Schoener, T. W. 1974. Resource partitioning in ecological communities. Science, 185: 27-39.

StatSoft, Inc. 1996. Statistica for Windows: computer program manual. Tulsa, StatSoft, Inc. Available from: http:// www.statsoft.com

Torloni, C. E. C., A. R. A. Corrêa, A. A. Carvalho Jr., J. J. Santos, J. L. Gonçalves, E. J. Gereto, J. A. Cruz, J. A. Moreira, D. C. Silva, E. F. Deus \& A. S. Ferreira. 1993. Produção pesqueira e composição das capturas em reservatórios sob concessão da CESP nos rios Tietê, Paraná e Grande, no período de 1986 a 1991. São Paulo, Série Pesquisa e Desenvolvimento, 73p.

Uieda, V. S., P. Buzzato \& R. M. Kikuchi. 1997. Partilha de recursos alimentares em peixes em um riacho de serra do Sudeste do Brasil. Anais da Academia Brasileira de Ciências, 69: 243-251.

Vidotto, A. P. \& E. D. Carvalho. 2007. Composition and structure of fish community in a stretch of the Santa Bárbara River influenced by Nova Avanhandava Reservoir (low Tietê River, São Paulo State, Brazil). Acta Limnologica Brasiliensia, 19(2): 233-245.

Vidotto-Magnoni, A. P. \& E. D. Carvalho. 2009. Population biology of dominant fish species of the Santa Bárbara River, a tributary of Nova Avanhandava Reservoir (low Tietê River, São Paulo State, Brazil). Acta Scientiarum, Biological Sciences, 31(1): 5563.

Winemiller, K. O. \& E. R. Pianka. 1990. Organization in natural assemblages of desert lizards and tropical fishes. Ecological Monographs, 60(1): 27-55.

Woodward, G. \& A. G. Hildrew. 2002. Food web structure in riverine landscapes. Freshwater Biology, 47(4): 777-798.

Accepted October 25, 2009

Published December 18, 2009 